\title{
MOBILE PASTORALISM AND SOCIO-ECONOMIC DEVELOPMENT AMONG RURAL FULANI COMMUNITIES IN KWARA STATE, NIGERIA
}

\author{
Raphael Abiodun OLAWEPO* \\ University of Ilorin, Department of Geography and Environmental Management, \\ PMB 1515, Ilorin, Kwara State, Nigeria, email: rafeola@unilorin.edu.ng
}

Afolabi Monisola TUNDE

University of Ilorin, Department of Geography and Environmental Management, PMB 1515, Ilorin, Kwara State, Nigeria, email: afolabi@unilorin.edu.ng

Nurudeen Adesola MALIK

University of Ilorin, Department of Geography and Environmental Management, PMB 1515, Ilorin, Kwara State, Nigeria, email: malik.na@unilorin.edu.ng

\author{
Abdulrazaq Kamal DAUDU \\ University of Ilorin, Department of Agricultural Extension and Rural Development, \\ PMB 1515, Ilorin, Kwara State, Nigeria, email: daudu.ak@unilorin.edu.ng
}

Citation: Olawepo, R.A., Tunde, A.M., Malik, N.A., \& Daudu, A.K. (2021). MOBILE PASTORALISM AND SOCIO-ECONOMIC DEVELOPMENT AMONG RURAL FULANI COMMUNITIES IN KWARA STATE, NIGERIA. Analele Universităţii din Oradea, Seria Geografie, 31(2), 133-142. https://doi.org/10.30892/auog.312104-863

\begin{abstract}
This study makes a spatial analysis of mobile pastoralism and socioeconomic problems among rural Fulani communities in Irepodun Local Government Area of Kwara State, Nigeria. Specifically, the study assesses the socioeconomic characteristics of mobile pastoralists; identify the length of stay of mobile pastoralists in their host communities and identify socioeconomic problems confronting Fulani herdsmen in their economic activities. A multistage sampling technique was employed to sample 740 Fulani herdsmen from twenty Fulani settlements and from four adjoining villages. Descriptive statistical techniques such as tables cross tabulations, percentages and graphs were employed to analyze the demographic characteristics of the pastoralists, length of stay in their host communities and other sources of income. Matrix scoring was used to rank the socioeconomic problems identified. The results revealed that the mean average age of sampled respondents was 44.8 years, $83.8 \%$ married and average household size of 11 people. Dwindling pasture, land degradation and drought were the most pressing socioeconomic problems identified. The study concludes by recommending adult education for the Fulani pastoralists as this will assist in enhancing and improving the socioeconomic life of the mobile pastoralists.
\end{abstract}

Key words: cattle rearers, rural communities, pastoralists and socio-economic problems

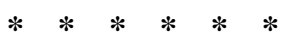

\footnotetext{
${ }^{*}$ Corresponding Author
} 


\section{INTRODUCTION}

The contributions of the agricultural sector to the economy of Nigeria cannot be overemphasized. Apart from contributing to the GDP, it also provides food as well as employment opportunity for the people of the country. Livestock rearing (Pastoralism) is one of the major agricultural activities performed by the Fulanis of Nigeria. There are 268 million people that practice pastoralism across the African continent, both as a way of life and a livelihood strategy, contributing between 10 to 44 percent of the GDP of African countries (Brottem \& McDonnell, 2020). Fulani are the main pastoral group in Nigeria with a population of approximately 15.3 million (Majekodunmi, Fajinmi, Dongkum, Shaw, \& Welburn, 2014). Pastoral farmers' livelihood is dependent on three key assets: firstly, accessibility to important landmarks such as animal healthcare, land, water, livestock, pasture, water, community networks, markets, education and loan facilities; secondly, the given environment where the assets are used together for production and consumption, specifically the political, organisational and institutional infrastructure where they are operative; and lastly, the risks involved (human and animal disease, drought and competition for natural resources) and vulnerability of livelihoods (Rass, 2006).

Mobile pastoralists in Nigeria keep different species of livestock and these include cattle, camels, small stocks and equines. Seasonal variation encourages pastoralists to move from dry areas to wet areas where their cattle can be well fed and have access to drinking water. They also move from areas that are prone to frequent droughts which often affect the pastoralists and their livestock. One of the most sustainable food systems in the world is pastoralism (International Union for Conservation of Nature, 2014).

Mobile Pastoralism is an age long tradition among Rural Fulani cattle rearers in most parts of Nigeria and other West African countries. This is a form of nomadic farming in which herders move livestock across landscape so that they can exploit recourses such as pasture and water that are variable in space and time. It is an ancient livelihood pattern in rural Nigeria, which contributes to food security, and plays vital role in the ecology of dry lands. It also provides pastoralists with flexible strategies for dealing with uncertainties, such as a variable climate (Shanahan, 2013).

The importance of the mobile and nomadic cattle herders in Nigeria cannot be farfetched. Apart from the fact that $90 \%$ of the meat need of the growing population is supplied by this group of herdsmen also contribute efficiently to the growing culture of the surrounding villages, as well as in the growth of cattle markets (Kara) in the vicinities where they are found. One major characteristic of the nomads here in Nigeria, is that they are mobile in all things, but some of them are now having semi-permanent residency.

There have been various incessant problems of conflicts revolving around mobile pastoralism in Kwara State in the last two decades. This deserves attention as a lot of such conflicts had led to loss of lives and properties on some occasion in Isanlu Isin, Oro-ago, Afon, Bode Saadu and in some localities around Osi and Erinmope in Ekiti Kwara. The issue of mobile pastoralism generates consensus around major policies and make political action possible. But they can also be problematic as they involve destruction of non-pastoralist means of livelihood like farming and land degradation.

Pastoralists are however confronted with many natural as well as man-made problems. Over some decades now, there have been cases of conflicts between mobile pastoralists and rural communities in Kwara State and other parts of Nigeria. The questions to ask are: What are the socioeconomic problems facing herdsmen? What are the coping strategies employed to cushion the effect of these socio-economic problems? Hence the purpose of this research is to examine the socioeconomic problems confronting the mobile Pastoralism among Rural Fulani Communities in Irepodun Local Government Area of Kwara State, Nigeria. Specifically, the study assesses socioeconomic characteristics of the mobile pastoralists; identified the socioeconomic problems confronting the herdsmen and evaluated coping strategies by mobile pastoralists and rural communities.

\section{MOBILE PASTORALISM}

Mobile pastoralism or transhumant is one of the major economic activities/livelihoods in the world. For instance, estimates of twenty million people are known to have been involved in pastoralist 
livelihoods in the Horn and East Africa region (OAU/IBAR Policy Briefing No. 2, cited in Hesse and MacGregor) (Hesse \& MacGregor, 2006). Keep varieties of livestock species such as cattle, goat and sheep. It is particularly common among the Fulanis of Nigeria. These herdsmen are economically important to Nigeria in several ways: These include provision of animal products in form of food such as beef meat and milk; provision of wool and leather for the teaming population. However, in the course of carrying out their economic activities, a lot of conflicts have been raised thereby causing economic problems. Pastoralists are confronted with many natural as well as man-made problems.

Based on the pattern of movement of the livestock, pastoralism is usually classified into nomadic, semi-nomadic, settled and semi-settled pastoralism (van Raay \& de Leeuw, 1974), or nomadic, semi-nomadic, semi-sedentary and sedentary pastoralists (de Weijer, 2002). Nomadic pastoralists migrate all the time with their livestock without any permanent settlement. Semi-nomadic pastoralists spend more than half their time annually herding animals away from home or cultivated settlements (Hunter, 1997). Further description (de Weijer, 2002) elaborates that semi-sedentary (semisettled) pastoralism is a system where the pastoralists settle (live in houses) during part of the year while part of the household moves with livestock to pasture, distinct from semi-nomadism where during movement the whole household moves. In sedentary pastoralism, the pastoralists live in villages all year round while taking livestock out to pasture every day, sometimes hiring shepherds.

The pattern of movement for nomadic pastoralists is random, non-directional. Movement of semi-nomadic and especially semi-settled or semi-sedentary pastoralists can be transhumant. This is a directional or regular back and forth movements between fixed locations, for example from mountains to the warmer valleys in winter and back to the mountains when it becomes warmer and frost has ceased.

Pastoralism is also based on enterprise system and degree of contact with cultivators (Frickle, 1978). This distinguishes pure pastoralism and agro-pastoralism, whereby pure pastoralism encompasses full-time livestock keeping ranging from those keepers with no consistent association with a particular farming or tenured land use system (nomads) to those who have more or less regular contact with cropping systems at their grazing sites. Agro-pastoralism, on the other hand, refers to livestock keeping while also practicing cropping. Accordingly (Hunter, 1997), agro-pastoralists are those farmers with animals who spend less than half their time in herding and more time in cultivation. The system exists in two sub-categories: sedentary agro-pastoralism and those who are transhumant. Sedentary agro-pastoralism is a system where livestock are kept throughout the year near cropping activities of the pastoralists.

\section{MATERIALS AND METHODS}

The study area for this research work is Irepodun L.G.A. The local government is located between latitude $8^{\circ} \mathrm{N}$ and $8^{\circ} 25^{\prime} \mathrm{N}$ and between longitude $4^{\circ} 40^{\prime} \mathrm{E}$ and $5^{\circ} 30^{\prime} \mathrm{E}$ [see figure 1] Irepodun Local Government was created out of Igbomina/Ekiti Division in 1976. The headquarters is in Omu Aran town. It has four districts: Omuaran, AjasseIpo, Esie/ijan and Oro districts. The L.G.A has eleven wards (AjaseIpo I, AjaseIpo II, Omu-Aran I, Omu-Aran II, Omu-Aran III, Oro I, Oro II, Esie/Ijan, Oko, Arandun and Ipetu/Rore/Aran Orin) and six area offices for administrative services. It has an area of $737 \mathrm{~km}^{2}$ and a population of 148,610 at the 2006 census (National Population Commission, 2006). It shares boundaries with Ifelodun L.G.A to the North, Osun to the South, Ekiti and Offa L.G.A to the East and West respectively. The L.G.A is populated by the Igbomina people of Yoruba cultural and historical significance Irepodun Local Government area has alternating climate of wet and dry season characterized with prevailing winds. The wet season is from April to November with about $1100-1500 \mathrm{~mm}$ of rain accompanied by the south westerly wind which originates from the Atlantic Ocean while the dry season starts in November and finishes in April characterized by harmattan. The climate condition favours the growth of food crops such as cassava, maize, guinea corn among others.

The area is on a gentle undulating land which falls within the older sedimentary rocks. The vegetation is savannah characterized by full grasses and shrubs. This is encouraged by high rainfall, 
high temperature and high relative humility. River Oshin is the only important river in the area. Other streams are seasonal. The soil of the area is edaphic in nature containing natural mineral resources. The economic activities of the people include farming (subsistence) and trading. Animal husbandry is being practiced by the nomadic Fulani in some communities of the study area. Other activities in the area include handicrafts, pottery, weaving, dyeing, leather works and embroidery making. The area also has small scale industries such as black smiting, gari processing, candles and leather products, among others.

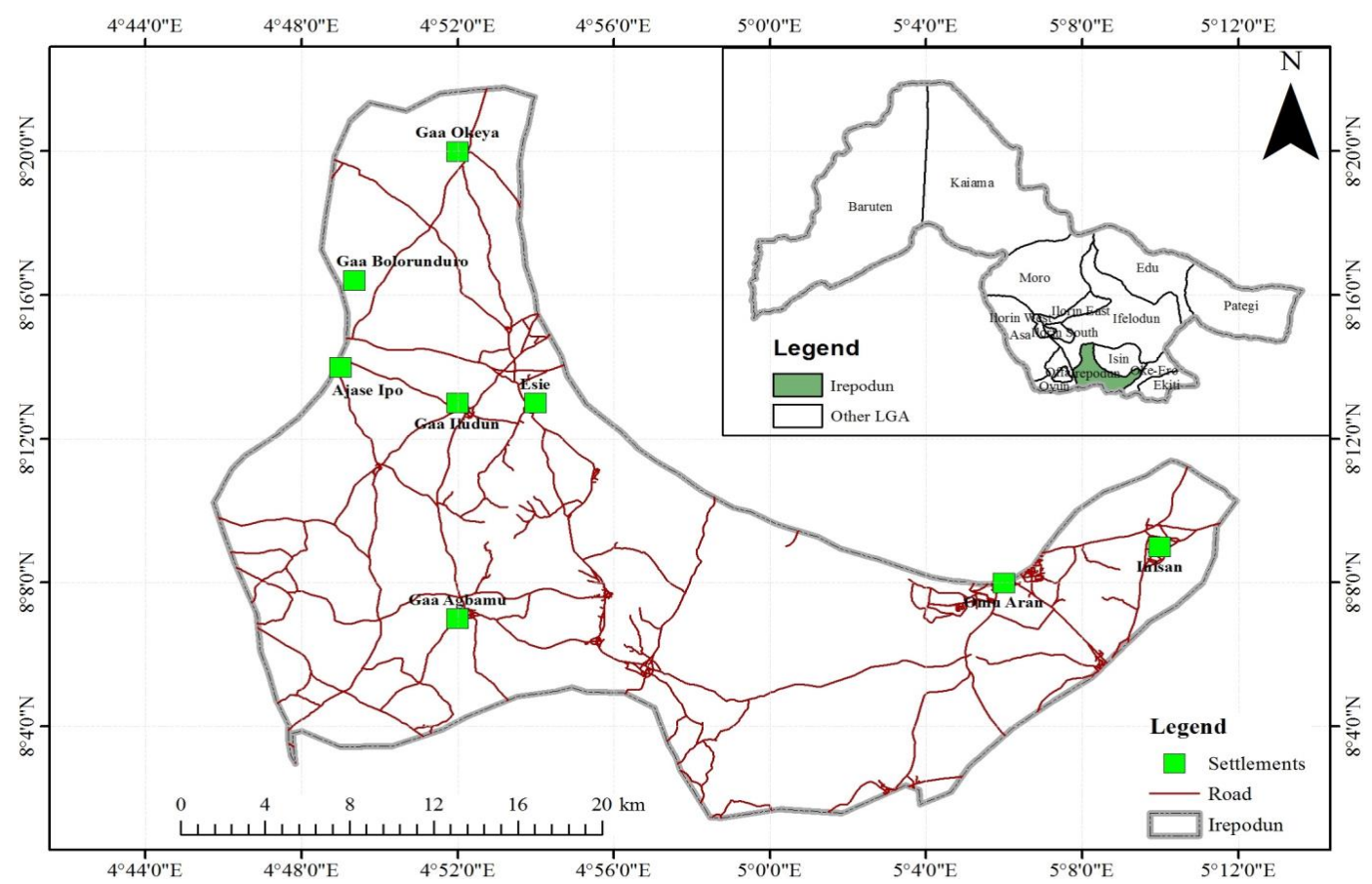

Figure 1. Irepodun Local Government Area showing the sampled settlements Source: Irepodun Local Government Area

Data for this study were sourced from primary and secondary sources. The primary data was collected through questionnaire administration while the secondary data were sourced from relevant documents in government agencies, related textbooks, journals and magazines.

A multistage sampling technique was employed. Using the four districts as sampling units first, the procedure involved selection of two districts (Omuaran and Ajase) from the four available, sampling ten villages in each district. From the eleven wards, based on the knowledge of the area under investigation all household heads in twenty Fulani settlements (gaas) and adjoining communities were sampled in the local government area. This brings the sampled respondents to 740. Descriptive statistical techniques such as tables, cross tabulations, percentages and graphs were employed to analyze the demographic characteristics of both the rural communities and the pastoralists; length of stay of the pastoralist in their host community and the distribution of pastoralist by size of herds. Matrix scoring such as ranking was used to rank socioeconomic problems identified.

\section{RESULTS AND DISCUSSION}

\section{Demographic characteristics of mobile pastoralists}

The result of the age distribution of the respondents is presented in Table 1. It was revealed that most (37.8\%) were between $41-50$ years old. $29.7 \%$ were between $31-40$ years old; $10.8 \%$ were between 51-60 years old; while $12.2 \%$ were above 60 years old and $9.5 \%$ were less than or equal to 30 years. 
However, the mean age was 44.8 years. This implies that most of the mobile pastoralists were still active and were within their productive age. Also, results from Table 1 showed that majority $(83.8 \%)$ of the respondents were married. Meanwhile, $9.5 \%$ were single while $2.7 \%$ were divorced, $1.4 \%$ was already separated and $2.7 \%$ were widowed. This implied that a high proportion of respondents had family responsibilities and would likely engage more in their economic activities intensely.

Table 1. Demographic distribution of respondents by age, marital status and household size Source: Field survey, 2018

\begin{tabular}{|c|c|c|c|}
\hline \multicolumn{2}{|c|}{ Category } & Frequency (f) & Percentage (\%) \\
\hline \multirow{7}{*}{ Age (Years) } & $\leq 30$ & 70 & 9.5 \\
\hline & $31-40$ & 220 & 29.7 \\
\hline & $41-50$ & 280 & 37.8 \\
\hline & $51-60$ & 80 & 10.8 \\
\hline & $>60$ & 90 & 12.2 \\
\hline & Mean & & 44.8 \\
\hline & Standard Deviation & & 11.5 \\
\hline \multirow{5}{*}{ Marital status } & Married & 620 & 83.8 \\
\hline & Single & 70 & 9.5 \\
\hline & Divorced & 20 & 2.7 \\
\hline & Separated & 10 & 1.4 \\
\hline & Widowed & 20 & 2.7 \\
\hline \multirow{6}{*}{ Number in household } & $1-5$ & 100 & 13.5 \\
\hline & $6-10$ & 320 & 43.2 \\
\hline & $11-15$ & 210 & 28.4 \\
\hline & $>15$ & 110 & 14.9 \\
\hline & Mean & & 11.0 \\
\hline & Standard Deviation & & 6.0 \\
\hline
\end{tabular}

Analysis of the size of the mobile pastoralists household in Table 1 showed that most of the respondents (43.2\%) had household size of around 6-10 people with the average household size of eleven (11) people. Large family size is assumed to be the source of labour, skills and strong social capital to adapt to changing situations. However, if only a few members of the household are engaging in productive livelihood activities that can support the family, large household size could be a burden to the family. The implication is that the relatively large household size may mean more people to cater for and, perhaps also more hands to herd animal.

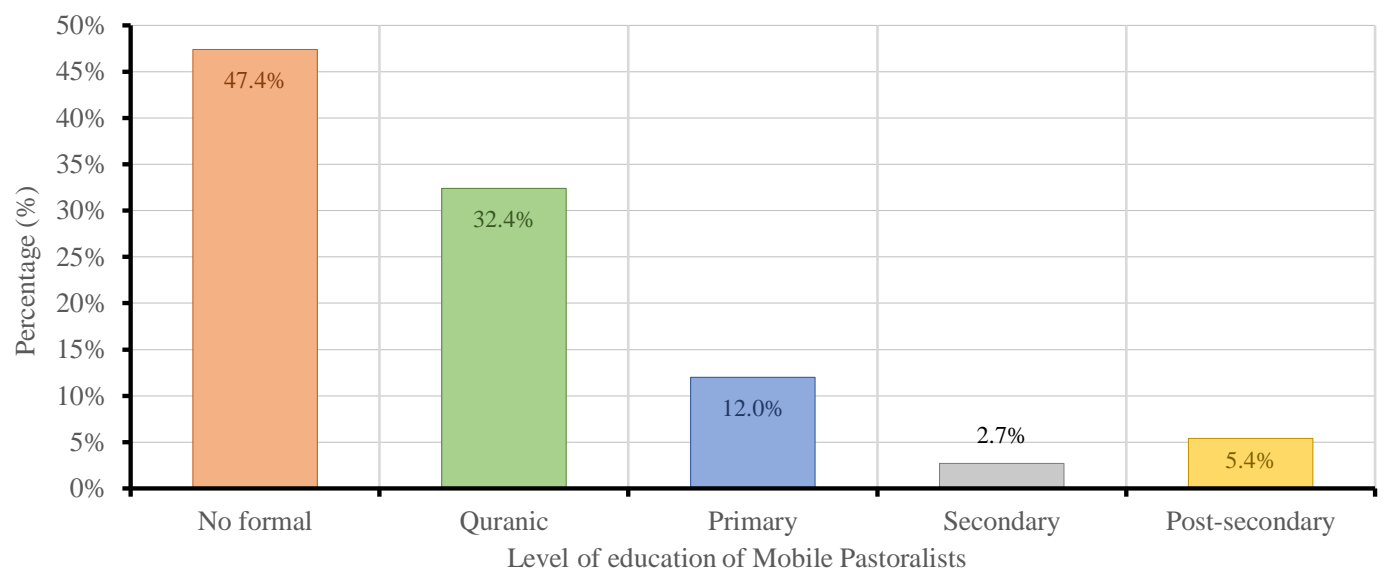

Figure 2. Demographic distribution of mobile pastoralists by level of education Source: Field survey, 2018 
The result of level of education of mobile pastoralists in Figure 2 showed that, $47.4 \%$ of them had no formal education. This suggests that illiteracy was still a common feature of mobile pastoralists, as about $32.4 \%$ had qur'anic education with $12 \%$ of them had primary education while only 2.7 and $5.4 \%$ had secondary and tertiary education respectively. The result implied that only few of mobile pastoralists were able taste the four walls of formal education in the study area.

Results in Table 2 revealed that the mean years of residence in host community of mobile pastoralists was 10.4 years and standard deviation of 14.3 years. Most $(48.5 \%)$ of mobile pastoralists who constitute reasonable percentage of youth were born in their host communities, $20.4 \%$ had being residing in the host community for 1-10 years while $20.3 \%$ have being with their host communities for about 11-20 years. This suggests that most mobile pastoralists have relatively part of their various host communities for at least a decade which could have make them familiar and acclimatized to the host communities. Also in Table 2, its discernible that the average monthly income of mobile pastoralists was relatively equivalent to $\mathrm{N} 31,693.68$ with majority $(63.5 \%)$ of them earn less than a hundred thousand per month while some 32.4 and 4.1\% earn between 101,000-200,000 and above 200, 000 respectively per month. This corroborates Majekodunmi et al., (Majekodunmi, Fajinmi, Dongkum, Shaw, \& Welburn, 2014) findings that the majority of pastoral households in Jos Plateau are in the middle wealth categories and only a few are poor in terms of livestock holdings.

Further results in Table 2 showed that about average (47.3\%) of mobile pastoralists engaged in other economic income generating activities including farming, trading and hunting.

Table 2. Distribution of mobile pastoralists by years of residence in host community, income and other sources of income

Source: Field survey, 2018

\begin{tabular}{|c|c|c|c|}
\hline \multicolumn{2}{|c|}{ Category } & Frequency (f) & Percentage (\%) \\
\hline \multirow{7}{*}{ Years of residence } & Born here & 359 & 48.5 \\
\hline & $1-10$ & 151 & 20.4 \\
\hline & $11-20$ & 150 & 20.3 \\
\hline & $21-30$ & 20 & 2.7 \\
\hline & $>30$ & 60 & 8.1 \\
\hline & Mean & & 10.4 \\
\hline & Standard Deviation & & 14.3 \\
\hline \multirow{5}{*}{ Income (N'000) } & $\leq 100$ & 470 & 63.5 \\
\hline & $101-200$ & 240 & 32.4 \\
\hline & $>200$ & 30 & 4.1 \\
\hline & Mean & & 31693.68 \\
\hline & Standard Deviation & & 70412.74 \\
\hline \multirow{6}{*}{$\begin{array}{l}\text { Other sources of } \\
\text { income }\end{array}$} & None & 390 & 52.7 \\
\hline & Fishing & 10 & 1.4 \\
\hline & Farming & 250 & 33.7 \\
\hline & Trading & 30 & 4.1 \\
\hline & Hunting & 10 & 1.4 \\
\hline & Farming \& Trading & 50 & 6.7 \\
\hline
\end{tabular}

The results in Table 3 showed that the mean herd was 51 and standard deviation of 26 . This implies that most mobile pastoralists in the study area had relatively small herd number which could fetch them relative low amount of income. The implication is that the larger the herd size the more the income and prone to farmer-herdsmen conflict because the herders have to feed their cattle. Table 2 showed that most $(60.8 \%)$ of mobile pastoralists had herd between 1 and $50,35.1 \%$ had herd size of 51-100 while only $4.1 \%$ had herd size greater than 100 . Also, the mean period of mobile pastoralism was 30.1 years and standard deviation of 13.3 years. Some $(10.8 \%)$ of mobile pastoralists spent up to 10 years in their host communities before they move on, $14.9 \%$ spent between 11-20 years while $36.5 \%$ and $37.8 \%$ spent between $21-30$ and above 30 years respectively. 
Table 3. Distribution of mobile pastoralists by size of herd and period of pastoralism Source: Field survey, 2018

\begin{tabular}{|c|c|c|c|}
\hline \multicolumn{2}{|c|}{ Category } & Frequency (f) & Percentage (\%) \\
\hline \multirow{5}{*}{ Size of herd (Number) } & $\leq 50$ & 450 & 60.8 \\
\hline & $51-100$ & 260 & 35.1 \\
\hline & $>100$ & 30 & 4.1 \\
\hline & Mean & & 51.0 \\
\hline & Standard Deviation & & 26.0 \\
\hline \multirow{6}{*}{$\begin{array}{c}\text { Period of mobile } \\
\text { pastoralism (Years) }\end{array}$} & $\leq 10$ & 80 & 10.8 \\
\hline & $11-20$ & 110 & 14.9 \\
\hline & $21-30$ & 270 & 36.5 \\
\hline & $>30$ & 280 & 37.8 \\
\hline & Mean & & 30.1 \\
\hline & Standard Deviation & & 13.3 \\
\hline
\end{tabular}

\section{CONFLICT EXPERIENCE OF MOBILE PASTORALISTS}

Results presented in Table 4 show the conflict experience of mobile pastoralists. The findings revealed that overwhelming majority $(82.3 \%)$ of mobile pastoralists had experienced one form of conflict or the other from other people within their host communities while a few of them have not experience conflict before. The findings also showed that majority (63.5\%) of mobile pastoralists had experienced conflict with crop farmers in their various host communities. These high figures indicate that farmer-herdsmen conflict is major form/type of conflict experienced by mobile pastoralists and which would continue to affects the quality of social relations between the herdsmen and their host communities (farmers). About $13.5 \%$ have had conflict with their fellow pastoralists/farmers, $2.7 \%$ had conflicted with their only fellow mobile pastoralists while $1.4 \%$ have had conflict with their cattle buyers and host communities. The mean frequency of conflict among mobile pastoralists and other was 4 and standard deviation of 1 . Results also revealed that about $41.9 \%$ of mobile pastoralists involved in conflict in a countless number. This suggests that mobile pastoralists may be more aggressive to cause conflict with other people. About $25.7 \%$ involved in conflict with other people over a thrice number of time while $12.2 \%$ and $2.7 \%$ have been involved in conflict with other people in twice and once in their life time respectively. Supporting this is Awoniran et al., (Awoniran, Olugbamila, \& Omisore, 2020) that discovered that food security is under threat in country.

Table 4. Distribution of mobile pastoralists by conflict experience Source: Field survey, 2018

\begin{tabular}{|c|c|c|c|}
\hline \multicolumn{2}{|c|}{ Category } & Frequency (f) & Percentage (\%) \\
\hline \multirow{2}{*}{$\begin{array}{c}\text { Experience of conflict } \\
\text { with other people }\end{array}$} & Yes & 610 & 82.3 \\
\hline \multirow{4}{*}{ If yes } & No & 130 & 17.6 \\
\cline { 2 - 4 } & Fellow pastoralist & 20 & 2.7 \\
\cline { 2 - 4 } & Crop farmers & 470 & 63.5 \\
\cline { 2 - 4 } & Fellow pastoralist/farmers & 100 & 13.5 \\
\cline { 2 - 4 } & Cattle buyers & 10 & 1.4 \\
\cline { 2 - 4 } & Host community & 10 & 1.4 \\
\hline \multirow{4}{*}{$\begin{array}{c}\text { Frequency of } \\
\text { involvement in conflict }\end{array}$} & Once & 20 & 2.7 \\
\cline { 2 - 4 } & Twice & 90 & 12.2 \\
\cline { 2 - 4 } & Thrice & 190 & 25.7 \\
\cline { 2 - 4 } & Countless & 310 & 41.9 \\
\cline { 2 - 4 } & Mean & & 1.0 \\
\cline { 2 - 4 } & Standard Deviation & & \\
\hline
\end{tabular}

\section{SOCIOECONOMIC PROBLEMS CONFRONTING FULANI HERDSMEN}

Fifteen socioeconomic problems were identified as confronting Fulani herdsmen in the study area as revealed in Table 5. From the table, dwindling pasture is the most pressing socioeconomic 
variable affecting Fulani herdsmen with a mean value of 3.82. This implies that the cattle rearers do not really have enough pasture for the cattle, hence, the need to move about in search of forage. Similarly, land degradation $(x=3.70)$ was ranked as another pressing socioeconomic problem confronting the herdsmen in tendering their cattle. This could also be as a result of change in climate. Drought has mean value of 3.47 and was ranked as another pressing problem facing the Fulani herdsmen. This can also be linked with seasonal rainfall as a result of climate change. Other problems include: threat to survivals, conflicts with non-pastoralists, poor clinical/extension services, dead livestock, housing the nomads, threat of violence, and dispute over resources, nomadic education, theft, mobility problems, shortage of labour, trespass/resource encroachment. Supporting this is Sacareanu et al., (Sacareanu, Floarea-Saghin, \& Sîrodoev, 2019) that reported that poor agricultural development represents a major problem in our society.

Table 5. Socioeconomic/Livelihood Problems confronting the mobile Fulanis in carrying out their economic activities

Source: Field survey, 2018

\begin{tabular}{|c|c|c|c|c|c|c|c|}
\hline Problems & \begin{tabular}{|c|} 
Strongly \\
Agree \\
$\{\mathbf{f}(\%)\}$
\end{tabular} & $\begin{array}{l}\text { Agree } \\
\{f(\%)\}\end{array}$ & $\begin{array}{c}\text { Disagree } \\
\{\mathbf{f}(\%)\}\end{array}$ & $\begin{array}{c}\text { Strongly } \\
\text { disagree } \\
\{f(\%)\}\end{array}$ & $\begin{array}{l}\text { Undecid } \\
\text { e }\{\mathbf{f}(\%)\}\end{array}$ & Mean & Rank \\
\hline Dispute over resources & $\begin{array}{c}20 \\
(2.7)\end{array}$ & $\begin{array}{c}20 \\
(2.7)\end{array}$ & $\begin{array}{c}420 \\
(56.8)\end{array}$ & $\begin{array}{l}200 \\
(27)\end{array}$ & $\begin{array}{c}80 \\
(10.8)\end{array}$ & 1.59 & $10^{\text {th }}$ \\
\hline Drought & $\begin{array}{l}400 \\
(54)\end{array}$ & $\begin{array}{c}320 \\
(43.2)\end{array}$ & $\begin{array}{c}5 \\
(0.7)\end{array}$ & $\begin{array}{c}5 \\
(0.7)\end{array}$ & $\begin{array}{c}10 \\
(1.4)\end{array}$ & 3.47 & $3^{\text {rd }}$ \\
\hline Threat of Violence & $\begin{array}{c}5 \\
(0.7)\end{array}$ & $\begin{array}{c}5 \\
(0.7)\end{array}$ & $\begin{array}{c}450 \\
(60.8)\end{array}$ & $\begin{array}{c}250 \\
(33.8)\end{array}$ & $\begin{array}{l}30 \\
(4)\end{array}$ & 1.60 & $9^{\text {th }}$ \\
\hline Conflicts with non-pastoralists & $\begin{array}{c}100 \\
(13.5)\end{array}$ & $\begin{array}{c}150 \\
(20.3)\end{array}$ & $\begin{array}{c}340 \\
(45.9)\end{array}$ & $\begin{array}{c}100 \\
(13.5)\end{array}$ & $\begin{array}{c}50 \\
(6.8)\end{array}$ & 2.20 & $5^{\text {th }}$ \\
\hline Trespass/resource encroachment & $\begin{array}{c}1 \\
(0.1)\end{array}$ & $\begin{array}{c}2 \\
(0.3)\end{array}$ & $\begin{array}{c}500 \\
(67.6)\end{array}$ & $\begin{array}{c}235 \\
(31.8)\end{array}$ & $\begin{array}{c}2 \\
(0.3)\end{array}$ & 0.47 & $15^{\text {th }}$ \\
\hline Theft & $\begin{array}{c}10 \\
(1.3)\end{array}$ & $\begin{array}{c}40 \\
(5.4)\end{array}$ & $\begin{array}{c}350 \\
(47.3)\end{array}$ & $\begin{array}{c}260 \\
(35.1)\end{array}$ & $\begin{array}{c}80 \\
(10.8)\end{array}$ & 1.51 & $12^{\text {th }}$ \\
\hline Dead Livestock & $\begin{array}{c}10 \\
(1.3)\end{array}$ & $\begin{array}{c}10 \\
(1.3)\end{array}$ & $\begin{array}{c}550 \\
(74.4)\end{array}$ & $\begin{array}{c}150 \\
(20.3)\end{array}$ & $\begin{array}{c}20 \\
(2.7) \\
\end{array}$ & 1.78 & $7^{\text {th }}$ \\
\hline Land degradation & $\begin{array}{c}420 \\
(56.8)\end{array}$ & $\begin{array}{c}300 \\
(40.4)\end{array}$ & $\begin{array}{c}5 \\
(0.7)\end{array}$ & $\begin{array}{c}5 \\
(0.7)\end{array}$ & $\begin{array}{c}10 \\
(1.4)\end{array}$ & 3.70 & $2^{\text {nd }}$ \\
\hline Threat to survivals & $\begin{array}{c}345 \\
(46.6)\end{array}$ & $\begin{array}{c}230 \\
(31.1)\end{array}$ & $\begin{array}{c}50 \\
(6.8)\end{array}$ & $\begin{array}{c}60 \\
(8.1)\end{array}$ & $\begin{array}{c}55 \\
(7.4)\end{array}$ & 3.20 & $4^{\text {th }}$ \\
\hline Mobility problems & $\begin{array}{c}2 \\
(0.3)\end{array}$ & $\begin{array}{c}3 \\
(0.4)\end{array}$ & $\begin{array}{c}300 \\
(40.5)\end{array}$ & $\begin{array}{c}410 \\
(55.4)\end{array}$ & $\begin{array}{c}25 \\
(3.4)\end{array}$ & 1.39 & $13^{\text {th }}$ \\
\hline Poor clinical/extension services & $\begin{array}{c}150 \\
(20.3)\end{array}$ & $\begin{array}{c}240 \\
(32.4)\end{array}$ & $\begin{array}{c}50 \\
(6.8)\end{array}$ & $\begin{array}{l}200 \\
(27)\end{array}$ & $\begin{array}{c}100 \\
(13.5)\end{array}$ & 2.19 & $6^{\text {th }}$ \\
\hline Dwindling pasture & $\begin{array}{c}630 \\
(85.1)\end{array}$ & $\begin{array}{c}102 \\
(13.8)\end{array}$ & $\begin{array}{c}1 \\
(0.1)\end{array}$ & $\begin{array}{c}2 \\
(0.3)\end{array}$ & $\begin{array}{c}5 \\
(0.7)\end{array}$ & 3.82 & $1^{\mathrm{st}}$ \\
\hline Housing the nomads & $\begin{array}{c}1 \\
(0.1)\end{array}$ & $\begin{array}{c}2 \\
(0.3)\end{array}$ & $\begin{array}{c}535 \\
(72.3)\end{array}$ & $\begin{array}{l}200 \\
(27)\end{array}$ & $\begin{array}{c}2 \\
(0.3) \\
\end{array}$ & 1.73 & $8^{\text {th }}$ \\
\hline Nomadic education pull & $\begin{array}{c}55 \\
(7.4)\end{array}$ & $\begin{array}{c}64 \\
(8.6)\end{array}$ & $\begin{array}{c}110 \\
(14.9)\end{array}$ & $\begin{array}{c}506 \\
(68.4)\end{array}$ & $\begin{array}{c}5 \\
(0.7)\end{array}$ & 1.53 & $11^{\text {th }}$ \\
\hline Shortage of labourers & $\begin{array}{c}1 \\
(0.1)\end{array}$ & $\begin{array}{c}3 \\
(0.4)\end{array}$ & $\begin{array}{c}100 \\
(13.5)\end{array}$ & $\begin{array}{c}630 \\
(85.2)\end{array}$ & $\begin{array}{c}6 \\
(0.8)\end{array}$ & 1.14 & $14^{\text {th }}$ \\
\hline
\end{tabular}

\section{COPING STRATEGIES EMPLOYED BY MOBILE PASTORALISTS}

The results in Figure 3 show the coping strategies employed among mobile pastoralists to ameliorate the socio-economic problems facing the pastoralists in the study area. Results showed that overwhelming majority (94.6\%) of mobile pastoralists avoid grazing on people's farm, $83.8 \%$ diversified into other economic income generating activities while $77 \%$ used drought tolerant breed of cattle. 


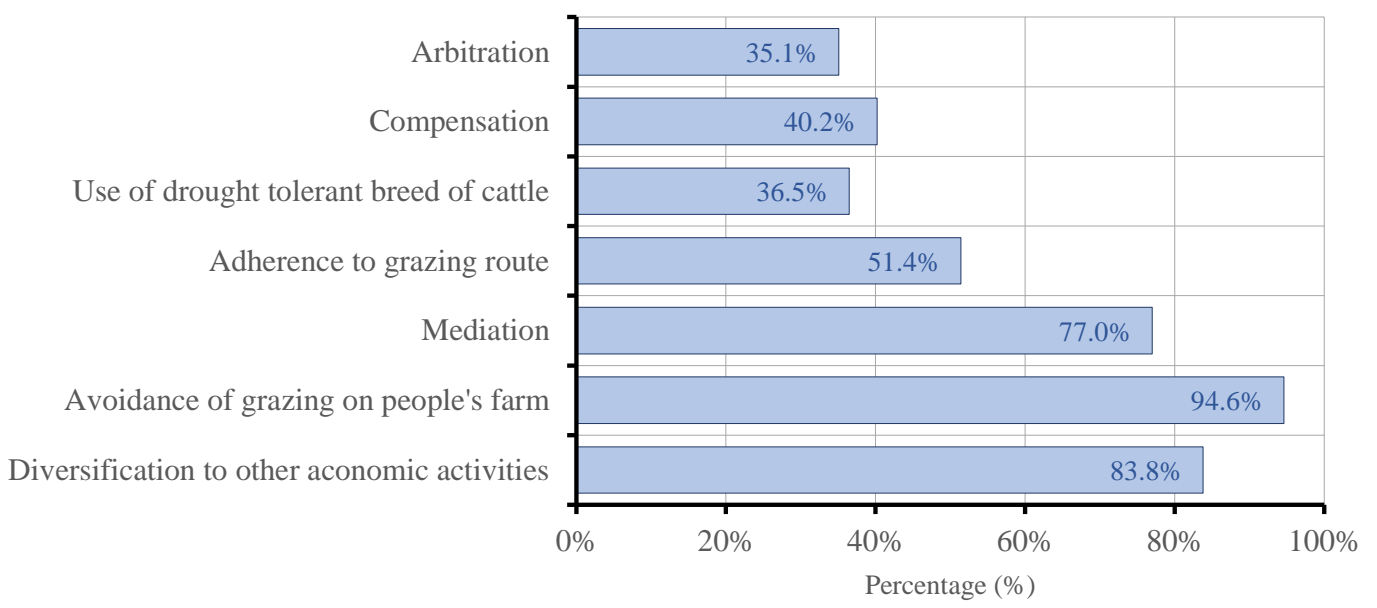

Figure 3. Coping strategies used by mobile pastoralists Source: Field survey, 2018

\section{MANAGING THE NOMAD'S PROBLEM}

Pastoral nomadism in West Africa is faced with a lot of problems ranging from socioeconomic to cultural problems as well as resource based.

Various solutions can be suggested especially if examined as affecting the cattle Fulanis. These include:
A. Central provision of folder cities, reserves and planting of grasses in peculiar locations. This will reduce long distant travelling and wondering of the nomads. This will also reduce clashes with farmers.
B. Provision of annually based buildings of locations of farming rural cities. If the nomads are housed majority of their problems are solved.
C. Provision of water ponds at ranching fields will serve a large proportion of the nomads and their cattle.
D. Government can organize modern cattle ranches in specified locations.
E. Veterinary centres, clinics and hospitals can be built at specified locations to treat cattle regularly. This could be supervised by the ministry of agriculture.
F. The Government can also increase extension services by training extension officers who should monitor and visit the Fulanis on the field.
G. Introduction and extension of nomadic education to all Fulani children. This will afford them the opportunity towards education and to sustain the future of cattle rearing.

H. Marketing broads can be introduced to assist the nomads to have regular prices for their products.

I. Massive production of animal feeds can be encouraged to assist in availability of food and feeders for animals during the dry season. This will also reduce travelling and distance coverage during the dry season.

J. There could also be inventory, records and tracking of all cattle rearers. This will help in monitoring them while on field as well as helping to know the range of stock in designated location. When they are traced and tracked, funds can be allocated for them and many of them will have access to capital, public goods and service.

\section{CONCLUSION}

The study had actually evaluated spatial analysis of mobile pastoralism and socioeconomic problems among rural Fulani communities in Irepodun Local Government Area of Kwara State, 
Nigeria. From the study, it was discovered that dwindling pasture, land degradation and drought were the most pressing socioeconomic problems identified. The implication of this is that there is possibility of food insecurity as the livelihood of the pastoralists in the study area is being threatened. It can therefore be concluded that awareness programme should be created for the Fulani pastoralists on how to manage their cattle as well as the pasture they feed on in order to reduce the problems being faced in rearing cattle in the study area. Recommendations made include provision of adult education for the Fulani pastoralists as this will assist in enhancing and improving the socioeconomic life of the mobile pastoralists. Also, there should be provision of infrastructure such as feasible dams and grazing reserves. There should be strict adherence to environmental law as well as monitoring the activities of the pastoralists as this will enhance food security in the country.

\section{REFERENCES}

Awoniran, D., Olugbamila, O., \& Omisore, E. (2020). Spatio-Temporal Analysis of the Practice of Urban Agriculture in Lagos Metropolis and the Implications for Urban Planning. Analele Universităţii din Oradea, Seria Geografie, 30(1), 76-87.

Brottem, L., \& McDonnell, A. (2020). Pastoralism and Conflict in the Sudano-Sahel: A Review of the Literature. Washington: Search for Common Ground.

de Weijer. (2002). Pastoralist vulnerability study (Final draft). AFSU/VAM Unit of World Food Programme.

Frickle, W. (1978). Cattle husbandry in Nigeria: A study of its Ecological Conditions and Socialanthropological Differentiations. Heidelberger Geographischen Arbeiten, 52.

Hesse, C., \& MacGregor, J. (2006). Pastoralism: Drylands' Invisible Asset? Issue Paper No. 142. IIED.

Hunter, M. (1997). The Challenge of Reaching Nomadic Pastoralists. International Journal of Frontier Missions, 14(4).

International Union for Conservation of Nature. (2014). Global Drylands Initiative (GDI) World Initiative for Sustainable Pastoralism (WISP). Retrieved from www.iucn.org/wisp/resources/publications/

Majekodunmi, A., Fajinmi, A., Dongkum, C., Shaw, A., \& Welburn, S. (2014). Pastoral livelihoods of the Fulani on the Jos Plateau of Nigeria. Pastoralism, 4(20). doi:https://doi.org/10.1186/s13570-014-0020-7

National Population Commission. (2006). Nigeria National Census: Population Distribution by Sex, State, LGAs and Senatorial District: 2006 Census Priority Tables (Vol. 3). Retrieved from http://www.population.gov.ng/index.php/publication/140-popn-distri-by-sex-state-jgas-andsenatorial-distr-2006

Rass, N. (2006). Policies and strategies to address the vulnerability of pastoralists in sub-Saharan Africa. ProPoor Livestock Policy Initiative, Food and Agriculture Organisation of the United Nations. Rome.

Sacareanu, G., Floarea-Saghin, I., \& Sîrodoev, I. (2019). Multi-Criteria Analysis of Agriculture in a Rural Space. Case Study: Argeș County. Analele Universităţii din Oradea, Seria Geografie, 29(1), 69-78. doi:https://doi.org/10.30892/auog.291108-800

Shanahan, M. (2013). Media Perceptions and Portrayals of Pastoralists in Kenya, India and China. Issue Paper No 154IIED.

van Raay, H., \& de Leeuw, P. (1974). Fodder Resources and Grazing Management in a Savanna Environment: an Ecosystem Approach. The Hague: Institute of Social Studies.

Submitted:

February 18, 2021
Revised:

November 24, 2021
Accepted and published online

December 2, 2021 